\title{
Record
}

\section{Dr Kenneth C. Maclure, AFC CD}

Kenneth Maclure, a Fellow of the Royal Institute of Navigation (1949), died suddenly on 24 March 1988 while on vacation in Mexico. He was one of the pioneers of modern polar navigation and a crew member of the Lancaster Aries, the first RAF aircraft to reach the north geographic pole.

His career in the RCAF began as a navigation instructor at the start of World War II. In 1941, while on the staff of the Empire Air Navigation School (EANS) at Shawbury, England, he proposed a grid system for measuring direction in high latitudes. The EANS was investigating methods of polar navigation at the time. In February 1945 the Air Ministry directed EANS to carry out a number of experimental flights in the region of the north magnetic and north geographic poles. The aircraft chosen was the Lancaster Aries which, under the same captain Wing Commander D. C. McKinley DFC, AFC, had completed a round-the-world flight in 1944 .

The polar flights with Wing Commander Maclure a crew member were completed in May 1945. The grid system, which he had proposed earlier, proved successful on all flights, one of which reached the north geographic pole. This polar exercise ushered in a new era of high latitude flying. A preliminary account of the Aries flights was given by Wing Commander Maclure at a meeting of the US Institute of Navigation in October 1945 and published in Navigation, Vol. 1, No. I, March 1946.

Wing Commander Maclure received the Air Force Cross for his contribution to the success of the Aries flights. The US Institute of Navigation honoured him with the Thurlow Award for 1945 for his contribution to polar navigation.

After World War II, Ken Maclure acquired a doctorate in nuclear physics from McGill University, and remained in the RCAF in a range of technical appointments, including a tour as defence scientist at the Canadian High Commission in London. He also was Air Attaché to Poland. In 1969 he retired from the armed forces with the rank of Group Captain, but continued to serve his country as a scientific officer with the Defence Research Board to which he had been seconded several times.

Dr Maclure continued his career as a scientific officer with the Department of National Defence until his retirement in 1979 , at which time he was Superintendent of the Pacific Naval Laboratory. The Laboratory was active in northern research, an interest which Ken had retained since his days at EANS.

On retiring from government service, Dr Maclure devoted much of his time to church affairs and to helping the handicapped and the less fortunate. This quiet, modest Canadian, a major contributor to modern-day polar navigation and northern research will be greatly missed by his associates as well as many others.

Keith R. Greenaway

\section{Harvey Fisher Schwarz}

Harvey Schwarz, who was the joint originator, with the late William J. O'Brien, of the Decca Navigator system, died on 23 April, aged 82 .

It was through his persistence and drive, coupled with a profound conviction of the 
technical merits of O'Brien's invention, that the system came to the Admiralty's attention in time for it to play a key part in the seaborne invasion of Normandy in 1944. The subsequent growth of 'Decca', as it has become known to mariners and airmen in their thousands, owed a great deal to Schwarz's dynamism as Managing Director of the Decca Navigator Company from 1950 to his retirement in 1970.

Harvey Fisher Schwarz was born in Edwardsville, Illinois, in 1905 . He received the BS degree in electrical engineering from Washington University, St Louis, in 1925 and in the same year joined the General Electric Company in Schenectady, NY, where he helped to develop the 'Radiola 44' which was the first domestic radio receiver to use the newly invented screened-grid valve. He later became chief engineer of the Brunswick Radio Corporation and it was there that he first met his future collaborator William O'Brien. In 1932 he was sent to England to design radios and radiogramophones for manufacture here and when Decca purchased Warner Brunswick he was persuaded to stay on as Decca's chief engineer. In the event he was to make his home in Britain although remaining a US citizen.

In 1939 O'Brien wrote to him setting out some ideas for a system of radionavigation that he felt might help the Allies. There followed a hectic period during which Schwarz was alternately helping O'Brien to develop and prove the system in their experimental laboratory in California and lobbying Service authorities in Britain. One of his many transatlantic flights (relatively adventurous in those days) brought him back to find the Decca factory bombed. His efforts were rewarded by Admiralty interest in O'Brien's system; three years later it was used with complete success to guide the leading minesweepers and landing craft on the Normandy invasion. The on-time production, by a small Decca team, of the shipboard and station-control equipment ordered about ten weeks before that operation owed much to Schwarz's enthusiasm and to his ingrained antipathy to the words 'it can't be done'.

After the war, when the system became commercially available as the Decca Navigator, Schwarz's attention focused increasingly upon the fact that it offered certain facilities (such as what has since become known as 'area navigation ') that are particularly desirable in a radio aid to navigation and traffic-control for civil aviation. Although the basic Decca Navigator system has come to be used by many more surface ships than aircraft, Schwarz's far-sighted concern with the growing problems of air navigation stimulated Decca engineers to develop a succession of airborne navigational computers and displays that were many years in advance of their time.

Despite these preoccupations he retained his interest in sound reproduction and recording and contributed personally to the development of Decca's 'FFRR' (full frequency range recording) technique.

Harvey Schwarz was an excellent host and his policy of generous Company hospitality made many friends. It also helped to form valuable links, at many levels, between the designers and the users of the Company's products. If the Decca Navigator enterprise may be said to have been fuelled by the expertise of Bill O'Brien and his technical staff, it was Harvey who supplied the ignition: in his pursuit of the operational and technical ideals that he cherished he was the proverbial ball of fire.

In 1956 he received, with O'Brien, the Gold Medal of this Institute for their work in originating and developing the Decca Navigator System. He was elected President of the (British) Institution of Electronic and Radio Engineers in 1969 and in the same year he and O'Brien received the Pioneer Award of the (US) IEEE Group on Aerospace and Electronic Systems. In 197 I Harvey Schwarz was appointed an Honorary CBE in recognition of his outstanding contribution to the safe navigation of ships and aircraft. Under him as Managing Director the Decca Navigator Company received two awards 
that gave him particular satisfaction : the 1959 Johnston Memorial Trophy of the Guild of Air Pilots and Navigators, and a US Navy Certificate of Merit for the part played by the Decca Hi-Fix system in recovering a lost nuclear weapon.

$\mathrm{He}$ is survived by a widow, herself a member of the team that build the Decca equipment for 'D-Day' and a son and daughter.

C.P.

$$
\text { Journal of Navigation - back issues }
$$

A limited number of back issues of the Journal are now available to Members for the cost of the post and packing. Please apply in writing to the Director.

There are no copies of Vol. I No. I, Vol. 5 No. I, Vol. 6 Nos 1, 2, Vol. I 3 No. 1, Vol. 14 Nos 1, 2. Bound copies are available in the RIN office or on loan for reference.

An updated index for Vols $\mathrm{I}-40$ is being prepared. 